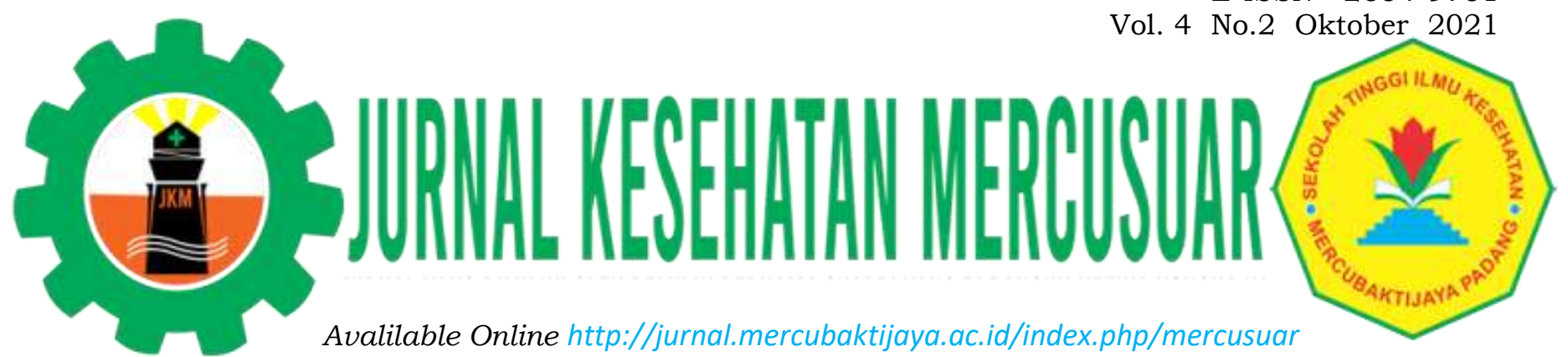

\title{
AKTIVITAS FISIK DAN TINGKAT DEPRESI LANSIA DI MASA PANDEMI
}

\author{
Yunita Sari ${ }^{1}$ \\ ${ }^{1}$ Diploma Tiga Keperawatan, Akademi Keperawatan Yatna Yuana Lebak, Jl. Jenderal Sudirman \\ Km 2 Rangkasbitung, Lebak, Banten 42315 \\ Email : sarie.yunitaa21@gmail.com
}

\begin{abstract}
COVID-19 has caused a pandemic in almost all parts of the world, including Indonesia. This has led to lockdown conditions in various countries. The Indonesian government is trying to break the chain of transmission of Covid-19, one of which is the Large-Scale Social Restriction (PSBB) which limits social and physical activities. One of the people affected by this policy is the elderly. Various studies have stated that physical activity will affect cognitive function and the level of depression in the elderly. The purpose of this study is to determine the relationship between physical activity and the level of depression in the elderly during a pandemic. This research is a descriptive corelative study with a cross sectional approach. Data were collected using A Physical Activity for the Elderly questionnaire to measure the physical activity in the elderly, and Geriatric Depression Scale to measure the level of depression. Bivariate statistical test using chi square. The results showed that there was no relationship between the level of physical activity and depression in the elderly during the pandemic ( $p$ value >0.05).
\end{abstract}

Keywords: physical activity; the level of depression in the elderly; covid-19 pandemi

\begin{abstract}
ABSTRAK
COVID-19 telah menimbulkan pandemic di hampir seluruh bagian di dunia, termasuk Indonesia. Hal ini menimbulkan kondisi lockdown di berbagai negara. Pemerintah Indonesia berupaya untuk memutus rantai penularan Covid-19, salah satunya dengan Pembatasan Sosial Berskala Besar (PSBB) yang membatasi aktivitas social dan fisik. Salah satu yang terdampak dari adanya kebijakan ini adalah lanjut usia. Dalam berbagai penelitian disebutkan bahwa aktivitas fisik akan mempengaruhi fungsi kognitif dan tingkat depresi lansia. Tujuan dari penelitian ini adalah mengetahui hubungan antara aktivitas fisik dan tingkat depresi lansia di masa pandemic. Penelitian ini merupakan penelitian deskriptif korelatif dengan pendekatan cross sectional. Data dikumpulkan dengan menggunakan kuesioner untuk mengukur aktivitas fisik lansia yaitu A Physical Activity for the Elderly dan mengukur tingkat depresi lansia dengan menggunakan Geriatric Depression Scale. Uji statistik bivariat dengan menggunakan chi square. Hasil menunjukkan bahwa tidak ada hubungan antara tingkat aktivitas fisik dan depresi lansia di masa pandemi ( $\mathrm{p}$ value $>0,05$ ). Tidak ada hubungan antara aktivitas fisik dan tingkat depresi lansia di masa pandemic.
\end{abstract}

Kata kunci: aktivitas fisik; tingkat depresi lansia; pandemic covid-19 


\section{PENDAHULUAN}

Pandemi merupakan wabah yang menjangkiti secara luas dan serempak meliputi wilayah geografis yang sangat luas. Sejak akhir tahun 2020, Wuhan sebagai salah satu kota di China telah mengalami penyakit infeksius ini. dan pada akhirnya WHO menetapkan virus Corona atau COVID-19 sebagai pandemi sejak Maret 2020 (Kemenkes, 2020b). Di lebih dari 100 negara di dunia telah mengalami pandemi virus corona atau covid-19, dan Indonesia merupakan salah satunya. Virus corona pertama kali ditemukan di Wuhan, China pada Desember 2019.

Corona Virus Disease 2019 atau disingkat dengan COVID-19 merupakan penyakit menular yang disebabkan oleh virus yang bernama Sarscov 2 yang merupakan coronavirus jenis baru yang belum pernah diidentifikasi sebelumnya pada manusia. Tanda dan gejala umum infeksi COVID-19 antara lain gejala gangguan pernapasan akut seperti demam, batuk dan sesak napas. Masa inkubasi rata-rata 5-6 hari dengan masa inkubasi terpanjang 14 hari. Pada kasus COVID-19 yang berat dapat menyebabkan pneumonia, sindrom pernapasan akut, gagal ginjal, dan bahkan kematian (Kemenkes, 2020b).

Pada era pandemi saat ini, kelompok lansia merupakan kelompok yang paling berisiko mengalami keparahan/morbiditas dan mortalitas akibat penyakit COVID-19. Data mortalitas akibat COVID-19 di beberapa negara menunjukkan peningkatan seiring dengan meningkatnya usia, seperti di Tiongkok jumlah kematian pada populasi usia 60-69 tahun sebesar 3.6\%, pada usia 7079 tahun sebesar $8 \%$ dan pada usia lebih dari 80 tahun sebanyak $14.8 \%$. Hal ini dikarenakan pasien lansia (geriatric) umumnya memiliki berbagai komorbiditas, seperti penyakit kardiovaskular, penyakit kencing manis, penyakit pernapasan kronik, hipertensi dan lain-lain. Seperti halnya di
Indonesia, dimana angka mortalitasnya meningkat seiring dengan meningkatnya usia yaitu pada populasi usia 45-54 tahun adalah 8\%, 55-64 tahun 14\% dan 65 tahun ke atas $22 \%$. Untuk itu pencegahan penularan melalui upaya promotif dan preventif kepada kelompok lansia sangat penting dilakukan, baik di tingkat keluarga, masyarakat dan fasilitas Kesehatan (Kemenkes, 2020a).

Pemerintah memberlakukan berbagai upaya dalam rangka meminimalkan angka penyebaran COVID-19, salah satunya adalah dengan pembatasan social berskala besar (PSBB). Kebijakan PSBB tersebut diatur dalam PP Nomor 21 Tahun 2020 tentang Pembatasan Sosial Berskala Besar dalam Rangka Percepatan Penanganan Covid-19 yang ditanda tangani oleh Presiden Joko Widodo. Selanjutnya, pelaksanaan PP itu diturunkan dalam Peraturan Menteri Kesehatan Nomor 9 Tahun 2020 tentang Pedoman PSBB (KOMPAS, 2020). Dengan adanya PSBB akan mempertegas batasan aktivitas social di masyarakat.

Salah satu aktivitas social yang biasa dilakukan oleh lansia adalah aktivitas fisik. Aktivitas fisik didefinisikan sebagai berbagai gerakan tubuh yang memerlukan energi misalnya berjalan, berbelanja, menyapu, termasuk juga didalamnya adalah aktivitas fisik yang terencana dan terstruktur dilakukan yaitu olahraga (Ambardini, 2009). Aktivitas fisik merupakan salah satu factor yang berkontribusi dalam peningkatan kesehatan fisik dan mental lanjut usia (Laporte et al., 1985). Aktivitas fisik juga akan mempengaruhi kondisi fisik lansia begitupula sebaliknya (Putra et al., 2018).

Aktivitas fisik bagi lansia memiliki banyak pengaruh bagi lansia. Aktivitas fisik diduga dapat menstimulasi pertumbuhan saraf yang kemungkinan dapat menghambat penurunan fungsi kognitif pada lansia (Muzamil et al., 2014). Aktivitas fisik yang dilakukan lansia akan dapat menstimulasi Brain Derived Neutrophic Factor (BDNF). 
Protein BDNF ini berperan penting menjaga sel saraf tetap bugar dan sehat. Selain itu, aktivitas fisik lansia berjalan dapat menurunkan tekanan darah (Khomarun et al., 2014). Selain berpengaruh terhadap fungsi kognitif dan fisik pada lansia, aktivitas fisik juga berpengaruh terhadap kondisi psikologis lansia. Penelitian Kurniawan dan Pramantara (2013) menunjukkan bahwa semakin tinggi tingkat aktivitas lansia maka akan semakin rendah level depresinya.

Seiring dengan kondisi pandemic saat ini, lansia cenderung mengurangi kegiatan atau aktivitas fisiknya dikarenakan adanya rasa takut tertular dan cemas (Yuliana, 2020). Olahraga ataupun aktivitas fisik yang lain yang dilakukan oleh lansia seperti berjalan akan sangat berguna bagi lansia untuk mencegah beberapa masalah kesehatan yang biasa dialami oleh lansia (García-Hermoso, A., Ramirez-Vélez, R., Sáez de Asteasu, M. L., Martínez-Velilla, N., Zambom-Ferraresi, F., Valenzuela, P. L., Lucia, A., \& Izquierdo, 2020). Lansia merupakan salah satu kelompok yang rentan untuk dapat tertular virus corona. Lansia mengalami pertambahan usia, sehingga fungsi fisiologis mengalami penurunan akibat proses penuaan. Apalagi lansia yang memiliki komorbid atau penyakit degenerative tertentu seperti jantung, DM, stroke, dan hipertensi. Sehingga kelompok lansia cenderung membatasi aktivitas fisiknya. Hal ini akan membuat lansia merasa kesepian. Pembatasan kontak social akan dapat mempengaruhi kontak emosiaonal dan ekspresi kasih sayang dari orang-orang terdekat yang dapat menimbulkan permasalahan baru yaitu depresi pada lansia. Sehingga penulis merasa perlu untuk mengkaji agar mendapatkan data yang berkaitan dengan bagaimana aktivitas lansia dan level depresi lansia di masa pandemi COVID-19 saat ini.

\section{METODE PENELITIAN}

Penelitian ini merupakan penelitian jenis kuantitatif bersifat deskriptif korelatif. Peneliti menggunakan pendekatan cross sectional dan akan mempelajari hubungan antara faktor risiko (variabel independen) yaitu tingkat aktivitas fisik dengan faktor efek (variabel dependen) yaitu tingkat depresi lansia yang diambil secara bersamaan pada satu waktu. Populasi pada penelitian ini adalah lanjut usia yang berada di wilayah puskesmas Rangkasbitung sebanyak 60 orang. Tekhnik sampling yang digunakan adalah purposive sampling. Sampel yang diambil untuk dilakukan penelitian ini adalah yang memenuhi kriteria inklusi yaitu lansia yang berusia diatas 60 tahun dan tidak sedang sakit fisik ataupun mengalami disabilitas, tidak mengalami gangguan penglihatan, tidak mengalami gangguan pendengaran, dapat diajak berkomunikasi, skor MMSE $\geq 7$ (fungsi intelektual utuh), serta bersedia menjadi responden penelitian. Data dikumpulkan dengan menggunakan kuesioner yang terdiri dari kuesioner 1 berisi tentang data demografi, bagian 2 berisi pertanyaan tentang aktivitas fisik dan bagian ke 3 mengenai tingkat depresi lansia. Kuesioner aktivitas fisik lansia menggunakan kuesioner baku untuk mengukur aktivitas fisik lansia yaitu A Physical Activity for the Elderly dan untuk mengukur tingkat depresi lansia digunakan kuesioner Geriatric depression scale. Data dianalisis dengan menggunakan Chi Square.

\section{HASIL DAN PEMBAHASAN}

Berdasarkan hasil penelitian, didapatkan gambaran karakteristik responden lansia sebagai berikut : 


\section{Tabel 1. Karakteristik Responden Penelitian Aktivitas Fisik Dan Tingkat Depresi Lansia Di Masa Pandemi}

\begin{tabular}{clcc}
\hline No & \multicolumn{1}{c}{ Variable } & $\mathrm{n}$ & $\%$ \\
\hline 1 & Usia : & 31 & \\
& a. Young old & 11 & $64,6 \%$ \\
& b. Middle age & 5 & $22,9 \%$ \\
& c. Old & 1 & $10,4 \%$ \\
& d. Very old & $2,1 \%$ \\
\hline 2 Jenis kelamin : & 16 & \\
& a. Laki-laki & $33,3 \%$ \\
& b. Perempuan & 32 & $66,7 \%$ \\
\hline 3 & Tingkat pendidikan : & & \\
& a. Tidak sekolah & 8 & $16,7 \%$ \\
& b. SD & 16 & $33,3 \%$ \\
& c. SMP & 6 & $12,5 \%$ \\
& d. SMA & 15 & $31,3 \%$ \\
& e. PT & 3 & $6,3 \%$ \\
\hline 4 & Status pernikahan : & & \\
& a. Tidak/belum menikah & 0 & $0 \%$ \\
& b. Menikah & 33 & $68,8 \%$ \\
& c. Janda/duda & 15 & $31,3 \%$ \\
\hline Tipe keluarga : & & \\
& a. Single/sendiri & 2 & $4,2 \%$ \\
& b. Inti & 10 & $20,8 \%$ \\
& c. Besar & 36 & $75 \%$ \\
\hline
\end{tabular}

Sumber : Data primer, 2021

Berdasarkan tabel di atas, dapat diketahui bahwa sebagian besar responden memiliki kategori usia young old (berusia $60-69$ tahun) sebanyak $64,6 \%$, berjenis kelamin perempuan sebanyak $66,7 \%$, sebagian besar responden adalah lulusan SD yaitu sebanyak $33,3 \%$. Untuk status pernikahan sebagian besar masih menikah $(68,8 \%)$ dan sebanyak $75 \%$ responden tinggal bersama keluarga besar. Sedangkan untuk gambaran tingkat aktivitas lansia dan tingkat depresi lansia dijelaskan sebagai berikut :

\section{Tabel 2. Gambaran Aktivitas Fisik Lansia di masa Pandemi}

\begin{tabular}{lcc}
\hline \multicolumn{1}{c}{ Aktivitas Fisik lansia } & Frekuensi & Persentase (\%) \\
\hline Rendah & 47 & $97,9 \%$ \\
\hline Tinggi & 1 & $2,1 \%$ \\
\hline Sumber : data primer, 2021 & &
\end{tabular}

Tabel 2 menunjukkan bahwa hampir seluruh responden memiliki tingkat aktivitas rendah yaitu 47 orang $(97,9 \%)$. 


\section{Tabel 3 Gambaran Tingkat Depresi Lansia di masa Pandemi}

\begin{tabular}{lcc}
\hline \multicolumn{1}{c}{ Tingkat Depresi Lansia } & Frekuensi & Persentase (\%) \\
\hline Normal & 21 & $43,8 \%$ \\
\hline Depresi & 27 & $56,3 \%$ \\
\hline
\end{tabular}

Sumber : Data primer, 2021

Tabel 3 menunjukkan bahwa sebagian besar responden mengalami depresi yaitu sebanyak 56,3\%. Hasil ini sesuai dengan penelitian Yusriana (2019) yang menyatakan bahwa sebagian besar lansia $(55,8 \%)$ mengalami depresi sedang/berat di Panti Sosial Tresna Werdha Sabai Nan Aluih Sicincin. Analisis bivariat digunakan untuk menjelaskan ada tidaknya hubungan antara aktivitas fisik dan tingkat depresi lansia di masa pandemic. Dari hasil analisis didapatkan :

\section{Tabel 4. Hasil Uji Chi Square Aktivitas Fisik Dan Tingkat Depresi Lansia Di Masa Pandemi}

\begin{tabular}{lccc}
\hline \multirow{2}{*}{ Aktivitas fisik } & \multicolumn{2}{c}{ Tingkat Depresi } & \multirow{2}{*}{ P value } \\
\cline { 2 - 3 } & Normal & Depresi & \\
\hline Rendah & 21 & 26 & 0,373 \\
\cline { 1 - 3 } Tinggi & 0 & 1 & \\
\hline
\end{tabular}

Tabel 4. menunjukkan bahwa sebanyak 21 responden dengan aktivitas rendah memiliki tingkat depresi yang normal (tidak depresi), sedangkan sebanyak 26 responden dengan aktivitas yang rendah mengalami depresi. Sebanyak 1 orang responden memiliki aktivitas fisik yang tinggi mengalami depresi. Hasil uji korelasi didapatkan p 0,373 ( $\mathrm{p}>0,05)$ menunjukkan bahwa tidak ada hubungan antara aktivitas fisik dengan tingkat depresi lansia di masa pandemic.

Hasil analisis hubungan antara aktivitas fisik dengan tingkat depresi lansia di masa pandemic diperoleh bahwa responden dengan aktivitas rendah memiliki tingkat depresi yang normal (tidak depresi) sebanyak 21 orang, sedangkan sebanyak 26 responden dengan aktivitas yang rendah mengalami depresi. Hasil uji statistic diperoleh nilai $\mathrm{p}=0,373$ maka dapat disimpulkan tidak ada hubungan antara aktivitas fisik dengan tingkat depresi lansia di masa pandemic. Hasil penelitian ini berbeda dengan penelitian Vossen., Collard. et al., (2014) yang menyatakan bahwa tingkat depresi pada lansia berhubungan dengan rendahnya level aktivitas fisik. Perbedaan ini menurut justifikasi peneliti dapat disebabkan oleh kondisi pandemic yang saat ini sedang berlangsung di beberapa negara dunia, termasuk Indonesia. Hasil penelitian Brown et al., (2021) menyebutkan bahwa banyak lansia yang mampu mengidentifikasi aspek positif dari kondisi lockdown dan lebih siap untuk menjalani lockdown.

Virus COVID-19 telah menyebar secara internasional yang mengakibatkan kondisi lockdown di berbagai negara termasuk 
Indonesia. Akibatnya, sebagian besar penduduk di Indonesia melakukan isolasi diri di rumah. Konsekuensi secara fisik dan psikologis dari kejadian ini merupakan suatu skenario yang tidak terduga yang dapat memunculkan suatu kekhawatiran khususnya bagi lanjut usia. Lanjut usia adalah seseorang yang telah mencapai usia 60 tahun ke atas (Maryam, R.S., Ekasari, M.F., Rosidawati, Hartini, T., Suryati, E.S., 2010). Lanjut usia merupakan kelompok rentan. Hal ini disebabkan karena lansia umumnya mengalami masalah kesehatan seiring dengan bertambahnya usia, yang disebabkan karena kekebalan dan daya tahan tubuh yang semakin mengalami penurunan, sehingga lansia mudah terserang berbagai penyakit (Kusuma, 2012). Konsekuensi yang mungkin muncul dari lansia adalah tertularnya lansia terhadap infeksi COVID19 yang dapat memunculkan tanda gejala yang serius atau komplikasi yang serius mengingat lansia pada umumnya memiliki berbagai komorbiditas, seperti penyakit kardiovaskular, penyakit kencing manis, penyakit pernapasan kronik, hipertensi dan lain-lain. Data mortalitas akibat COVID -19 di beberapa negara menunjukkan peningkatan seiring dengan meningkatnya usia, seperti di Tiongkok jumlah kematian pada populasi usia 60-69 tahun sebesar $3.6 \%$, pada usia $70-79$ tahun sebesar $8 \%$ dan pada usia lebih dari 80 tahun sebanyak $14.8 \%$. Sedangkan di Indonesia pada populasi usia 45-54 tahun adalah 8\%, 55-64 tahun $14 \%$ dan 65 tahun ke atas $22 \%$. Untuk itu upaya pencegahan penularan melalui promotif dan preventif kepada kelompok lansia sangat penting dilakukan, baik di tingkat keluarga, masyarakat dan fasilitas Kesehatan (Kemenkes, 2020a).

Salah satu tindakan yang dilakukan pemerintah adalah dengan membatasi kegiatan/aktivitas masyarakat untuk mencegah penularan COVID-19. Kebijakan ini tertuang dalam PP Nomor 21 Tahun
2020 tentang Pembatasan Sosial Berskala Besar dalam rangka Percepatan Penanganan Covid-19 (KOMPAS, 2020). Dengan adanya kebijakan ini, maka akan mempertegas batasan aktivitas social dan aktivitas fisik di masyarakat. Sesuai dengan hasil penelitian Salman, D; Beaney, T; Robb (2020) yang menunjukkan bahwa rata-rata aktivitas fisik pada lansia mengalami penurunan setelah diberlakukannya lockdown. Adanya kebijakan lockdown yang diberlakukan sejak Maret 2020 lalu dan kondisi lansia yang tergolong kelompok rentan akan membuat lansia cenderung untuk tidak melakukan aktivitas fisik di luar rumah atau berinteraksi dengan orang lain. Hal ini sesuai dengan hasil penelitian Brown et al., (2021) yang menyatakan bahwa kondisi lockdown membuat lansia beraktivitas kurang dibandingkan dengan sebelum lockdown. Selain itu hal lain yang dapat menyebabkan adalah adanya kedekatan dan dukungan dari anggota keluarga lansia. Sesuai dengan Prinadiyanty (2018) yang menyebutkan bahwa dukungan keluarga merupakan salah satu factor yang mempengaruhi tingkat depresi. Pada penelitian ini, tingkat depresi tidak berhubungan dengan aktivitas fisik. Hal ini disebabkan karena sebagian besar lansia (75\%) tinggal bersama keluarga besarnya. Sehingga dimungkinkan lansia memperoleh dukungan yang berasal dari keluarga dalam berbagai bentuk. Sesuai dengan hasil penelitian Moeini et al., (2018) yang menyatakan bahwa dukungan sosial akan mampu meningkatkan level kebahagiaan, sehingga secara tidak langsung akan berdampak pada status psikologisnya. Pada penelitian ini, sebanyak $39,7 \%$ responden tinggal bersama dengan paling sedikit 3 anggota keluarga. Bentuk dukungan yang diberikan antara lain dukungan sosial, emosional, informasional, instrumental, dan appraisal. Hasil penelitian menunjukkan bahwa setiap bentuk dukungan sosial 
memiliki korelasi yang positif dengan level kebahagiaan lansia. Lansia yang hidup dengan anggota keluarga, termasuk pasangan dan anak-anak, akan dapat memperoleh perhatian dan berbagai bentuk dukungan termasuk finansial dan emosional, sehingga menciptakan perasaan dicintai, diperhatikan yang mampu meningkatkan harga diri lansia, sehingga mengarah pada kehidupan yang bahagia dan sehat (Moeini et al., 2018). Senada dengan hasil penelitian Bozo O, Toksabay NE, (2009) yang mengungkapkan bahwa responden yang menerima dukungan sosial memiliki tingkat depresi yang minimal.

\section{SIMPULAN}

Kesimpulan yang didapatkan dari penelitian ini antara lain :

1. Sebagian besar responden berusia young old, berjenis kelamin perempuan, dan tingkat pendidikan paling banyak adalah SD. Untuk status pernikahan, Sebagian besar lansia menikah dan tinggal bersama dengan keluarga besarnya (anak, menantu, cucu).

2. Tingkat aktivitas fisik lansia selama pandemic dalam kategori aktivitas rendah.

3. Sebagian besar lansia mengalami depresi di masa pandemic ini.

4. Tidak ada hubungan antara aktivitas fisik lansia dengan tingkat depresi di masa pandemic.

\section{UCAPAN TERIMAKASIH}

Penulis mengucapkan terimakasih kepada Pusat Penelitian dan Pengabdian Masyarakat AKPER Yatna Yuana Lebak yang telah memberikan dukungan baik moral maupun material sehingga penelitian ini dapat dilakukan.

\section{DAFTAR PUSTAKA}

Ambardini, R. . (2009). Aktivitas Fisik pada Lanjut Usia.

Bozo O, Toksabay NE, K. O. (2009). Activities of daily living, depression, and social support among elderly Turkish people. J Psychol., 2(143), 193-205.

https://doi.org/10.3200/JRLP.143.2.193 $-206$

Brown, L., Mossabir, R., Harrison, N., Brundle, C., Smith, J., \& Clegg, A. (2021). Life in lockdown: A telephone survey to investigate the impact of COVID-19 lockdown measures on the lives of older people ( $\geq 75$ years). Age and Ageing, 50(2), 341-346. https://doi.org/10.1093/ageing/afaa255

García-Hermoso, A., Ramirez-Vélez, R., Sáez de Asteasu, M. L., MartínezVelilla, N., Zambom-Ferraresi, F., Valenzuela, P. L., Lucia, A., \& Izquierdo, M. (2020). Safety and Effectiveness of Long-Term Exercise Interventions in Older Adults: A Systematic Review and Meta-analysis of Randomized Controlled Trials. Sports Medicine (Auckland, N.Z.), 6(50), 1095-1106. https://doi.org/https://doi.org/10.1007/s 40279-020-01259-y

Kemenkes, R. (2020a). Panduan Pelayanan Kesehatan Lanjut Usia Pada Era Pandemi COVID-19. Direktorat Kesehatan Keluarga, Dirjen Kesehatan Masyarakat.

Kemenkes, R. (2020b). Pedoman pencegahan dan pengendalian Covid19.

https://covid19.go.id/storage/app/media /Protokol/REV-

05_Pedoman_P2_COVID-

19_13_Juli_2020.pdf

Khomarun, Nugroho, M. A., \& Wahyuni, E. S. (2014). Pengaruh Aktivitas Fisik 
Jalan Pagi Terhadap Penurunan Tekanan Darah Pada Lansia Dengan Hipertensi Stadium I Di Posyandu Lansia Desa Makamhaji. Jurnal Terpadu Ilmu Kesehatan, 3, 106-214. http://jurnal.poltekkessolo.ac.id/index.php/Int/article/view/97

KOMPAS. (2020). Penerapan Physical Distancing Diperkuat Melalui Kebijakan PSBB. https://nasional.kompas.com/read/2020/ 04/10/18195851/jubir-pemerintahpenerapan-physical-distancingdiperkuat-melalui-kebijakan.

Kurniawan; Pramantara. (2013). Hubungan antara aktivitas fisik dengan tingkat depresi pada lansia di Panti Werdha Budi Luhur Bantul. Repository UGM. http://etd.repository.ugm.ac.id/penelitia n/detail/62385

Kusuma, W. (2012). Perawatan Usia Lanjut. Jakarta : Rineka Cipta.

Laporte, R. E., Montoye, H. J., \& Caspersen, C. J. (1985). Assessment of physical activity in epidemiologic research: Problems and prospects. Public Health Reports, 100(2), 131-146.

Maryam, R.S., Ekasari, M.F., Rosidawati, Hartini, T., Suryati, E.S., N. (2010). Asuhan Keperawatan pada Lansia. Jakarta : TIM.

Moeini, B., Barati, M., Farhadian, M., \& Ara, M. H. (2018). The association between social support and happiness among elderly in Iran. Korean Journal of Family Medicine, 39(4), 260-265. https://doi.org/10.4082/kjfm.17.0121

Muzamil, M. S., Afriwardi, A., \& Martini, R. D. (2014). Hubungan Antara Tingkat Aktivitas Fisik dengan Fungsi Kognitif pada Usila di Kelurahan Jati Kecamatan Padang Timur. Jurnal Kesehatan Andalas, 3(2), 202-205. https://doi.org/10.25077/jka.v3i2.87

Prinadiyanty, D. N. (2018). Faktor-Faktor yang Mempengaruhi Pemanfaatan
Posyandu Lansia di Puskesmas Padang Bulan. Journal of Health Studies, 11(1), 110-122.

Putra, K. P., Kurniasari, M. D., \& Adeoka Purnamasiwi. (2018). Analisa hubungan aktivitas fisik terhadap kondisi fisik lansia di desa dan kota. Seminar Nasional Pendidikan Jasmani UMMI Ke-1 Tahun 2018, 2, 235-243. http://eprints.ummi.ac.id/466/

Salman, D; Beaney, T; Robb, C. (2020). 1. Faculty of Medicine, Imperial College London, UK. Digital Economies at Global Margins, 44(0). https://doi.org/10.7551/mitpress/10890. 003.0026

Vossen., Collard., V., D, H. C. C., \& E, Hilde M. de Vocht, Naarding, P. (2014). Physical ( in ) Activity and Depression in Older People. 161, 6572.

Yuliana. (2020). Menjaga Kesehatan Mental Lansia Selama Pandemi COVID-19 Corona Virus Disease 2019 ( COVID19 ) telah menghantui sebagian besar pikiran beberapa obat-obatan secara rutin karena ada tujuan untuk memberikan pengetahuan Dampak COVID-19 terhadap Kesehatan yan. Prosiding Seminar Biologi Di Era Pandemi CIVID-19, September, 6-10. http://journal.uin-

alauddin.ac.id/index.php/psb/article/vie w/14956/9526

Yusriana, Y. Y. (2019). Hubungan Status Konsep Diri Dengan Kejadian Depresi Pada Lansia Di Panti Sosial Tresna Werdha Sabai Nan Aluih Sicincin. Jurnal Kesehatan Mercusuar, 2(1), 8. https://doi.org/10.36984/jkm.v2i1.27 